\title{
Socio-Economic Distribution and Higher Education Participation of Students in Kenya
}

\author{
John Mugun Boit ${ }^{1, *}$ \\ ${ }^{1}$ School of Arts and Social Sciences, Moi University, P.O.Box 3900 - 30100 Eldoret, Kenya \\ *Correspondence: School of Arts and Social Sciences, Moi University, P.O.Box 3900 - \\ 30100 Eldoret, Kenya. Tel: 254-721-625-657. E-mail: jmugunboit@gmail.com
}

Received: July 6, 2015 Accepted: August 18, 2015 Published: August 26, 2015

doi:10.5296/ije.v7i3.7971 URL: http://dx.doi.org/10.5296/ije.v7i3.7971

\begin{abstract}
The disparity in higher education participation is a perverse problem in most developing countries. The purpose of this study was to examine the socio-economic distribution of students and higher education participation of students in Kenya from three dimensions: students' parents socio-economic backgrounds, parental occupational status, and parental level of education. The survey sample compromising 581 respondents was selected from three higher education institutions namely; a public university, a private university and a polytechnic institution. Findings indicatethat despite the overall expansion towards mass systems imbalances in participation based on student socio-economic background is a major factor in Kenyan higher education institutions. The study reveals that higher education is selective, not only in terms of type of secondary school students attended but across parental traits such as father's education and occupation. The economic capacity of parents is very crucial in determining who can take advantage of the best available education provision and how far a student goes up the education ladder. These findings further confirm the perverse social selection and class bias in higher education institutions with students from lower socioeconomic backgrounds less likely to participate in higher education as students from middle and higher socioeconomic backgrounds. This makes higher education access in Kenya to be highly inequitable. This disproportionate representationpresents a major challenge for education policy. In order to achieve equity and enhance access to tertiary level education, amongst all socio-economic groups, the government should seriously address disparities in school outcomes, both at primary school level and between the various secondary school types and barriers to access that are due to financial obstacles.
\end{abstract}

Keywords: higher education, parents' occupational status, parents level of education, socio-economic background, universities 


\section{Introduction}

Higher education is considered to have substantial economic returns. Apart from benefits higher education accrues to society in terms of creation of a pool of trained and skilled manpower able to manage vast amounts of knowledge and technology for increased productivity and economic growth, it has very real direct individual benefits. Individualswith higher education are likely to be happier, healthier and more democratically tolerant (Schuller et al. 2004). They are better placed to secure well-paid jobs and have access to positions of greater influence, wealth and power including controlling factors of production(Baum, Ma, \& Payea, 2013; Naidoo, 2007; Psacharopoulus \& Patrinos, 2004). Higher education is, therefore, arguably the best form of investment in the future. Relatively few academic studies on the crucial question of education and equity have been undertaken in Kenya.

Only a handful of individual academic studies that relate school achievement of students and social background have been done in Kenya. One such early study by Maundu (1986) examined student achievement in science and mathematics in secondary schools. Parents' occupational status and the level of formal education attained constituted a measure of socio-economic status. Occupations were grouped into four categories: professional/managerial, skilled, commercial/self-employed, and unskilled jobs. Examples of professional/managerial occupations included university lecturers and professors, medical doctors, and company managers. Those in skilled jobs included mechanics, cashiers, bursars, and technicians. Under self-employed category were grocery sellers and shopkeepers. Office messengers, farmers, and cooks were classified under unskilled occupations. According to the study, parental levels of education were found to be significantly different for students attending the extra-provincial (national), provincial and "harambee" (district) secondary schools. More than half (57 per cent) of students in extra-provincial schools came from family backgrounds where the father had at least form four standard of education. This was in comparison to 37 per cent in provincial and 23 per cent in "harambee" schools. A similar trend for mothers' level of education was correspondingly observed across the three school types. In extra-provincial schools, 36 per cent of students had mothers with at least form four level of education, 17 per cent in provincial schools and 7 in the "harambee" schools.

Socio-economic and regional participation imbalances in also evident in most developed nations. A number of studies related to higher education participation carried out in OECD countries since the early seventies and eights(OECD 2006a; OECD 2006b) show that, although expansion of higher education systems in Europe and America during the 1960s and 1970s widened opportunities for students from a working background, upper-class entrants in higher education were still by far the most important single numerical group. More recent studies in Australia, Sweden, Germany and UK have not found any significant increases in the participation rate from working class children (James, 2012; Universities in Australia 2008; James 2002; Blanden, \& Gregg, 2004).

A study of the socio-economic distribution of students at the National Autonomous University of Honduras cited by Ziderman and Albrecht, (1995)showed that despite 
governments' efforts to increase participation of students from low income groups through its open access policy and payment of token fees, 66 per cent of students came from families that had higher annual incomes of U\$ 2500 and 6 per cent of the students were from families with incomes below U\$1130 (Ziderman and Albrecht, 1995). The reason the policy (open access) did not have the desired effects, according to Ziderman and Albrecht occurrence in most developing countries. Another example of the extent to which socio-economic background influences the rate of university participation of the various socio-economic groups is demonstrated by a study carried out in 1990 at the University of the Philippines. It was found that 77 per cent of the students came from families that owned cars and 77 per cent of the students had fathers who were professionals.

In another study titled 'Education, Productivity, and Inequality,' involving Kenya and Tanzania, Knight and Sabot (1990) found, using parental level of education as an equity dimension, that there was a strong correlation in both countries between the father's education and the level of education achieved by the employee. Put in another way, the percentage of employees attaining higher levels of education increased with parents' level of education.

Knight and Sabot's conclusions, in the Kenyan study, are similar to those of the OECD studies regarding the effects of policies aimed at democratising educational access through quantitative expansion. Both studies confirmed that the children from more privileged backgrounds tend to remain one step ahead in educational attainment.

According to Knight and Sabot (1990), equalisation of opportunities at the lower secondary level through quantitative expansion does not necessarily equalise opportunities at the next level. Proportionately fewer children from less privileged backgrounds tend to get promoted into the tertiary system which has the effect of increasing inequality in the distribution of places at the tertiary level and disproportionately benefiting children from the more privileged background. Consequently intergenerational mobility gains achieved in a democratised secondary school system are neutralised and even reversed at the tertiary level. .

Similarly, recent studies in Australia (James, 2012; Bowden \& Doughney, 2010; Stevenson et al., 2000; Universities in Australia 2008) found a high correlation between parental level of education and their children's higher education participation. Students whose parents had high levels education had access to a variety of resources which leveraged their participation in university studies. They identified influences such as role models, information resources, educational aspirations and expectations as potential encouraging factors in highly educated homes. In other words 'educogenic' families tend to be more motivating to their children.

\subsection{Statement of the Problem}

Inequities in higher education participation remain a problem in Kenya. Studies on equality of opportunity show that socio-economic background influences the rate of university participation of the various socio-economic groups (Chowdry, 2013; Machin, \& Vignoles, 2004).Entrants in higher education ofupper socioeconomic backgroundsare still by far the 
most important single numerical group. There is justifiable concern on this trend of differential rates of access to higher education in Kenya for two major reasons. First, there is the objective of social justice and the equal rights of all Kenyans to enjoy the personal and economic benefits that education, particularly higher education, might confer. Second, to reduce the risk of Kenyans getting marginalized in a knowledge-based society where labour markets require sophisticated skills. This study is therefore important as it will provide policy makers, researchers and educational planners with useful information that will assist them in formulating policies on higher education provision particularly in addressing issues of imbalances of participation amongst all socio-economic groups, as Kenya transits into a mass higher education system.

\subsection{Purpose of the Study}

The purpose of this study was to analysethe socio-economic composition of students enrolled in higher education in Kenya in terms of their parental level of education and occupation in order to determine higher education participation of the various socioeconomic groups.

\subsection{Objectives of the Study}

a) To analyse the socio-economic composition of students enrolled in higher education.

b) To compare and contrast the socio-economic distribution of students enrolled in higher education.

c) To identify the socio-economic groups that was more likely to gain access to higher education in Kenya.

\section{Methodological Rationale and the Research Design}

This survey research adopted quantitative methods of data collection with the aim of obtaining valid and reliable data that is amenable to generalisation. The research questions were, therefore, designed to elicit quantifiable data to enable description and generalisations to be made to the population being studied (Creswell, 2012; Hair et al., 2010; Bryman, 2007). The design process of this survey consisted of two phases, planning phase; scope of the research, formulation of the research plan and execution phase; design, data collection and analysis (Burke, \& Chritensen, 2012).

\subsection{Sample Size, Sampling Techniques and Data Collection Instruments}

A sample comprising 40 per cent of first year students (the target population) was considered to be an appropriate sample size for this study. Consequently a representative sample of first year studentswas randomly selected from each of the three respective institutions and administered with a hundred percent return rate at Moi University with a first year student enrolment of 1025 students - 409 respondents; Eldoret Polytechnic with 250 students - 99 respondents and the University of East Africa, Baraton with 190 students -73 respondents from the respective faculty courses. 
Self-administered survey questionnaire was used to collect data as it was considered most appropriate and suitable for collecting data from survey research studies such as this one. In order to answer the question who gains access to higher education and to determine the socio-economic groups that were more likely to benefit from higher education respondents in this study were divided into five socio-economic status (SES) groups labelled as: SES(i)-low, SES(ii)-middle low, SES(iii)-middle, SES(iv)-middle high and SES(v)-high. To arrive at the SES groups, the means of the five social and economic indicators comprising occupation and education status of father and mother respectively and family income were calculated. Raw scores were first transformed into $\mathrm{Z}$ scores. Mean scores were then obtained for each of the respondents. On the family data, questions such as type of family/marital union, level of education attained by parents, family assets, type of family house and availability of a range of consumer and household goods etc. were asked.

These variables were used to examine, describe and analyse socio-economic similarities and differences of first year students enrolled in the three types of higher education institutions. First year students around whom data were collected and analysed constituted the unit of analysis in this study. In order to answer the question who gains access to higher education and to determine the socio-economic groups that were more likely to benefit from higher education participation or to be disproportionately represented in higher education, respondents in this study were divided into five socio-economic status (SES) groups labelled as: SES (i)-low, SES (ii)-middle low, SES (iii)-middle, SES (iv)-middle high and SES (v)-high. To arrive at the SES groups, the means of the five social and economic indicators comprising occupation and education status of father and mother respectively and family income were calculated. All these measures of SES have been shown to be strong indicators of access to higher education and have a strong correlation between them (Blanden \& Machin, 2004; James, 2002). Raw scores were first transformed into $Z$ scores. The mean scores that were obtained for each of the respondents were then subdivided into five SES groups in accordance with the Stanfive Scale.

Stanfive Scale, based on Stannine Scale standard score system, enables normal distribution scores to be divided into five parts ranging from 1 to 5 . Score 1 , being the lowest, score 5 , the highest, and score 3, the middle point of the distribution (Borg and Gall, 1989). Score 1 shares 6.68 per cent (about 7 per cent) of the respondents, score 2 shares 24.17 per cent (about 24 per cent), score three shares 38.3 per cent ( about 38 per cent), score 4 shares 24.17 per cent (about 24 per cent) and score 5 shares 6.68 per cent (about 7 per cent). The intervals between 1 and 5 are, therefore, as follows: score 1 has less than 7 per cent of the respondents or raw scores; score 2 has between 7-31 per cent, score 3 between 31-69 per cent, score 4 between 69-93 per cent and score 5 greater than 93 per cent.

To determine the number of respondents in each of the five SES groups the percentage share of each group was multiplied by the total number of respondents in the sample (581). For example, 41 or 7 per cent of the respondents with the lowest mean scores were in SES (i). This was obtained by multiplying 7 per cent by 581 - the total number of respondents in the sample. Similarly, 139 or 24 per cent of the respondents with the second lowest mean scores were in SES (ii). This was obtained by multiplying 24 per cent by 581 . Using the same 
method 221 or 38 per cent of the respondents were in SES (iii); 139 or 24 per cent of the respondents were in SES (iv) and 41 or 7 per cent of the respondents were in SES (v).

There were not many cases of missing information particularly with regard to the five variables used to calculate the socio-economic index. However, where a respondent had missing information in one or two variables a mean score was obtained for the variables with full information. On the whole there were less than 12 per cent of cases with missing information in one or two of the five critical variables. This is considered a small percentage to invalidate the results of the analysis (Creswell,2012; Hair et al., 2010)

With regard to parental occupational status, the respondents in this survey were asked to state as specifically as possible the actual job their parents did. Examples were given to assist them towards clear responses, for example, primary school teacher, major in the army, retail trader, lorry driver, farmer, fisherman/woman, doctor, clerk, messenger, nurse etc. The occupational status scale adopted in this study follows the tradition of comparable survey overseas and in particular is similar to that used in the OECD study of 1975(Western et.al, 1998; Ziderman and Albrecht, 1995) because it reflects similar job categories in the Kenya as a developing country. Job categories and rankings used in recent studies for developed countries to determine SES are not quite as relevant to this study since they are newer and jobs such as computer professionals are held by young professionals who are too young to have children of their own studying in higher education. The respondent SES were categorised on the basis of status classification based on occupational prestige. In other words, the occupational scale followed some fairly clear status hierarchy. The social groups that were derived are considered to share similar life-styles and social and material circumstances. The following occupational rankings were used:

1. Independent and high professional: self-employed lawyers, engineers, computer professionals,

Judges

2. Salaried professional, manager, executive: university lecturers

3. Semi-professional, low executive, administrative position: secondary school teachers, college tutors

4. Senior clerical/middle level personnel: primary school teachers, technician

5. Self -employed small businesses: traders, small businesses

6. Skilled manual: mechanics, carpenters

7. Semi-skilled manual: farmers, fishermen

8. Unskilled manual: Servants, hawkers, vendors, labourers

These classes were later regrouped into five broader occupational categories to enable the data to be analysed. In doing this, care was taken to ensure that only closely related occupations were merged. The following occupational categories are, therefore, used 
throughout this study to refer to respondents' parents' occupations:

- Professional/managerial - combined 1 and 2

- Semi-professional/secondary teachers - 3

- Middle-level /senior clerical- 4

- Self-employed /skilled manual - combined 5 and 6

- Farming/ semi-skilled- combined 7 and 8.

With regard to the highest level of education attained by parents, respondents were given four levels of education to choose from namely, $1=$ no formal education, 2 = primary, $3=$ secondary and 4 = university. Education is considered an important means for upward mobility, with the better educated enjoying a higher quality of life as evidenced by their higher frequency of material possession.

The completion of secondary school is the main means of accessing university study. Secondary school education system is characterised by a three-tier structure consisting of national, provincial and district schools. The national secondary schools are considered to be the best, highly competitive and selective schools in the land. Provincial schools, on the other hand, are rated second best and equally competitive. The third type of schools, the district secondary schools, is considered to be least competitive, least selective in terms of students' scholastic abilities and least rated of the three types. These are local schools largely initiated and supported by the local communities. They are also poorly equipped in almost all respects. They have inadequate books, laboratory facilities, poor staff housing and lack of highly qualified and experienced teaching staff. The respondents were therefore asked to indicate the type of secondary school they attended. Type of secondary is considered a good indicator of the socioeconomic background a student was likely to come from.

\subsection{Validity and Reliability}

The survey questionnaire containing items checking on respondents SES; level of fathers' education; level of mothers' education; type of secondary school attended and fathers' occupation; was tested for accuracy and whether it was actually measuring what it was intended to measure by piloting the questionnaire on sixty first year students in three institution of higher education similar to the ones that participated in the study. This was also to check for typographical errors, spelling mistakes, ambiguous instructions, and length of the survey, survey layout and format, cultural sensitivity of questions, appropriateness of items for the respondents, appropriateness and level of language for the respondents (Creswell,2012; Hair et al., 2010)

Internal reliability was computed using SPSS for Windows program version 16 and a Cronbach's Alpha reliability coefficient result of 0.8860 was obtained and the questionnaire was thus adjudged to have made the reliability threshold of 0.7 to be used in the study (Winter, 2000). 


\subsection{Data Analysis Techniques}

Research data were analysed, in accordance with the research objective, using descriptive and chi-square statistics with the aid of SPSS computer statistical package (Creswell, 2011; Hair et al., 2010). The chi-square test of independence statistic was used to see whether there were any associations between the dependent and independent variables in this study. Further the data to be analysed were categorical and the analysis did violate chi-square requirement that $20 \%$ of the cells had expected counts less than 5 (Hair et al., 2010). The conventional significance levels, alpha $(\alpha)$, used in this study to test hypothesesis $0.05 ; 0.01$ and 0.001 .

\section{Results}

This study examined the question 'Who gains access to higher education in Kenya' from three dimensions: socio-economic backgrounds of parents, parents' level of education and parents occupations.

\subsection{Respondents Socio-economic Background}

A cross tabulation analysis was run on respondents' socio-economic background by institution of higher education and the results are presented in table 1 below.

Table 1. Institution of Higher Education by Respondents SES

\begin{tabular}{lllllll}
\hline \multirow{2}{*}{ Items } & \multicolumn{3}{c}{ Institution of higher education } \\
& Moi University & \multicolumn{2}{c}{ UEA Baraton } & \multicolumn{2}{c}{ Eldoret Polytechnic } \\
\cline { 2 - 8 } & (f) & column\% & (f) & column \% & (f) & column \% \\
\hline Socio Economic Status & & & & & & \\
Low SES(i) & 39 & $(9.5)$ & 1 & $(1.4)$ & 1 & $(1.0)$ \\
MiddleLow SES(i) & 117 & $(28.6)$ & 6 & $(8.2)$ & 16 & $(16.2)$ \\
Middle SES(iii) & 152 & $(37.2)$ & 21.9 & $(53)$ & 53 & $(53.5)$ \\
Middle high SES(iv) & 85 & $(20.8)$ & 30 & $(41.1)$ & 24 & $(24.2)$ \\
High SES(v) & 16 & $(3.9)$ & 20 & $(27.4)$ & 5 & $(5.1)$ \\
\hline
\end{tabular}

Key: (f) frequency count, $\mathrm{N}=581$

The results in Table 1show that lower status families SES (i) (9.5\%) were more likely to enrol at Moi University than at the UEA, Baraton(1.4\%) or Eldoret Polytechnic(1\%). In contrast, family households of middle background status and above were more likely to enrol at Eldoret Polytechnic, that is, SES (iii) (53.5\%) followed by middle high SES (iv) $(24.4 \%)$ middle low SES (ii)(16.4\%), high SES (v)(5.1\%) and low SES (i)(1.0\%). At the UEA, Baraton higher SES groups (iv)(41.1\%) and (v)(27.4\%) were, however, dominant with SES (ii)(8.2\%) and SES (i)(1\%) least represented. 
3.2 Respondents Level of Parental Education and Type of Secondary Attended

Table 2. Type of Secondary School Respondents Attended by Highest Level of Fathers' Education

\begin{tabular}{|c|c|c|c|c|c|c|c|c|}
\hline \multirow{3}{*}{ Items } & \multicolumn{6}{|c|}{ Highest level of respondents' fathers' education } & \multirow{2}{*}{\multicolumn{2}{|c|}{ University }} \\
\hline & \multicolumn{2}{|c|}{ No formal Education } & \multicolumn{2}{|c|}{ Primary } & \multicolumn{2}{|c|}{ Secondary } & & \\
\hline & (f) & column $\%$ & (f) & $\operatorname{Imn} \%$ & (f) & column \% & (f) & column \% \\
\hline \multicolumn{9}{|c|}{ Type of secondary school } \\
\hline District and others & 31 & 44.9 & 49 & 38.6 & 52 & 26.4 & 14 & 12.1 \\
\hline Provincial & 33 & 47.8 & 68 & 53.5 & 118 & 59.9 & 69 & 59.5 \\
\hline National & 5 & 7.2 & 10 & 7.9 & 27 & 13.7 & 33 & 28.4 \\
\hline
\end{tabular}

According to the findings presented in Table 2, respondents who attended district type secondary schools came from family backgrounds where the father, was least educated with either primary level education $(44.9 \%)$ or with no formal education $(38.6 \%)$ at all. Those who attended provincial secondary schools were equally likely to have fathers' who had secondary school level of education (59.9\%) and University education $(59.5 \%)$ followed by fathers with primary education (53.5\%) and lastly fathers with no formal education (47.8\%). Respondents who attended national secondary schools were most likely to come from households where fathers had university education (28.4\%) followed by secondary education (13.7\%), less likely with primary $(7.9 \%)$ and least likely with no formal education $(7.2 \%)$. The chi-square result between the type of secondary school respondents attended and level of their fathers' education was significant $(\chi 2=45.5 ; 6 \mathrm{df} ; \mathrm{p}<.001$ at $\mathrm{p}<.001)$. This means that the two variables in the population of first year students in the three institutions are dependent i.e. the type of secondary school attended was dependent on the highest level of schooling of respondents' father.

\subsection{Respondents' Highest Level of Fathers' Education by Institution of Higher Education}

A cross-tabulation of these two variables, respondents' highest level of fathers' education by institution of higher education is presented in table 3 .

Table 3. Respondents' Highest Level of Fathers' Education by institution of higher education

\begin{tabular}{lllllll}
\hline Items & \multicolumn{4}{l}{ Institution of higher education } & \\
& \multicolumn{2}{l}{$\begin{array}{l}\text { Moi } \\
\text { University Baraton }\end{array}$} & \multicolumn{2}{c}{ Polytechnic } \\
\cline { 2 - 6 } & \multicolumn{2}{l}{ Count Col \% Count } & Col \% & Count & Col \% \\
\hline Highest level of father's Education & & & & & \\
No formal education & 58 & $16.6 \%$ & 3 & $4.4 \%$ & 8 & $8.7 \%$ \\
Primary & 95 & $27.2 \%$ & 71 & $0.3 \%$ & 25 & $27.2 \%$ \\
Secondary & 135 & $38.7 \%$ & 22 & $32.4 \%$ & 40 & $43.5 \%$ \\
University & 61 & $17.5 \%$ & 36 & $52.9 \%$ & 19 & $20.7 \%$ \\
\hline & & & & & &
\end{tabular}


The results show that 16.6 percent of respondents at Moi University indicated that their fathers had no formal education, 4.4 percent at the UEA, Baraton and 8.7 percent at Eldoret Polytechnic. Respondents at the UEA, Baraton (10.3 percent) were least likely to have fathers with primary level of education while Moi University (27.2 percent) and Eldoret Polytechnic (27.2 percent) were equally likely to have parents with primary level of education as indicated by equal proportions of responses on this item. However, of the three institutions, Eldoret Polytechnic (43.5 percent) was more likely to have respondents whose fathers had secondary school level education than MoiUniversity (38.7 percent) or the UEA, Baraton (32.4 percent). Over half (52.9) of the respondents at the UEA, Baraton had fathers with university level education compared to Eldoret Polytechnic (20.7 percent) and Moi University (17.5 percent).

The results of chi-square analysis between respondents highest level of fathers' education by type of institution produced a highly significant chi-square value $(\chi 2=47.9 ; 6 \mathrm{df} ; \mathrm{p}<.001)$ indicating that the level of respondents fathers' education was significantly different in the three institutions studied with highly educated parents with the ability to pay high fees enrolling their children at UEA Baraton followed by Eldoret polytechnic.

Table 4. Respondents' Highest Level of Mothers’ Education

\begin{tabular}{|c|c|c|c|c|c|}
\hline \multirow{3}{*}{ Items } & \multicolumn{5}{|c|}{ Institution of higher education } \\
\hline & \multirow{2}{*}{$\begin{array}{l}\text { Moi University } \\
\text { (f) column \% }\end{array}$} & \multirow{2}{*}{\multicolumn{2}{|c|}{$\frac{\text { UEA Baraton }}{\text { (f)column \% }}$}} & \multicolumn{2}{|c|}{ Eldoret Polytechnic } \\
\hline & & & & (f) & column \% \\
\hline \multicolumn{6}{|c|}{$\begin{array}{l}\text { Highest level of Mothers } \\
\text { Education }\end{array}$} \\
\hline No formal education & 23.6 & 4 & 5.5 & 16 & 16.3 \\
\hline Primary & 35.8 & 11 & 15.1 & 37 & 37.8 \\
\hline Secondary & 33.8 & 33 & 45.2 & 38 & 38.8 \\
\hline University & 6.7 & 25 & 34.2 & 7 & 7.1 \\
\hline
\end{tabular}

As indicated in table 3 above respondents enrolled at Moi University were more likely to come from households where mothers had no formal education $(23.6 \%)$, than those enrolled in Eldoret polytechnic(16.3\%) and less likely at UEA Baraton(5.5\%). However, respondents with mothers having primary level education were more or less equally likely to be enrolled at Eldoret polytechnic (37.8\%) as at Moi University (35.8\%)and less likely at UEA Baraton(15.1\%).At UEA Baraton respondents' mothers were likely to have secondary education(45.2\%) followed by those at Eldoret polytechnic(38.8\%) and at Moi University (33.8\%). Similarly respondents at UEA Baraton were most likely to have mothers with University education(34.2\%) compared to Eldoret Polytechnic(7.1\%) and Moi University(6.7\%). It appears respondents at UEA Baraton and Moi University had better educated mothers at every count. A chi-square test of independence was significant $(\chi 2=68.6$; $6 \mathrm{df} ; \mathrm{p}<.001$ ) indicating an association between better educated mothers and the likelihood of students attending better rated secondary schools and thereby increasing their chances of 
access to higher education.

Table 5. Type of Secondary School Respondents Attended By Institution of Higher Education

\begin{tabular}{lllllll}
\hline \multicolumn{7}{c}{ Institution of higher education } \\
\hline Items & \multicolumn{7}{c}{ Moi university } & \multicolumn{2}{c}{ UEA Baraton } & \multicolumn{2}{c}{ Eldoret polytechnic } \\
\cline { 2 - 7 } & (f) & column \% & (f) & column \% & (f) & column \% \\
\hline \multicolumn{2}{l}{ Type of secondary school } & & & & & \\
District \& others & 126 & 30.8 & 126 & 30.8 & 29 & 29.3 \\
Provincial & 219 & 53.5 & 43 & 58.9 & 66 & 66.7 \\
National & 64 & 15.6 & 19 & 26.0 & 4 & $4.0 \%$ \\
\hline
\end{tabular}

The respondents who attended district and other type secondary schools were equally likely to enrol at Moi University (30.8\%), Eldoret Polytechnic (30.8\%) and UEA Baraton (29.3). Those who studied in provincial secondary schools were more likely to enrol at Eldoret Polytechnic(66.7\%) schools followed by UEA Baraton (58.9\%) and Moi University $(53.5 \%)$ while at national schools more likely to enrol at the UEA, Baraton $(26.0 \%)$ than at the other two institutions, Moi University(15.6\%) and Eldoret Polytechnic (4.0\%). The results of chi-square analysis indicate a significant association between the type of secondary school respondents attended and type of institution they were studying $(\chi 2=21.89525$, df $4 ; p<.01$ $\mathrm{p}<.01)$.

3.4 Fathers' Occupation

Table 6. Type of Secondary School Attended by Respondents Fathers' occupation

\begin{tabular}{llllll}
\hline \multicolumn{5}{c}{ Respondents' Fathers' occupation } \\
\hline Item & Farming/sem & Self-employed & Middle & Semi & Professional- \\
& i-skilled & Small-business & level & profess/secondary. & manager \\
& & Primary-teacher & skilled & Teacher & \\
& (f)column \% & (f) column \% & $\begin{array}{l}\text { (f)column } \\
\text { (f) column \% }\end{array}$ & (f) column \% \\
& & & & \\
\hline
\end{tabular}

Type of school

Attended

\begin{tabular}{llrlrllllll} 
District & 107 & 40.1 & 12 & 32.4 & 11 & 16.4 & 9 & 11.3 & 5 & 9.1 \\
Provincial & 138 & 51.7 & 22 & 59.5 & 45 & 67.2 & 51 & 63.8 & 30 & 54.5 \\
National & 22 & 8.2 & 3 & 8.1 & 11 & 16.4 & 20 & 25.0 & 20 & 36.4 \\
\hline
\end{tabular}

$\mathrm{N}=506$

In terms of respondents' fathers' occupational status, respondents who attended district secondary schools (and who were likely to enrol at Moi University table 4) were more likely to have fathers who were largely from farming/semi-skilled (40.1\%) or self-employed and small scale business backgrounds (32.4\%). Respondents who attended provincial schools 
(and who were most likely to be enrolled at Eldoret polytechnic and UEA, Baraton, table 4) were more likely to come from family backgrounds where the fathers were either middle level/skilled (67.2\%) or semi-professional/secondary school teacher status(63.8\%). However those who attended national schools (and were most likely to be enrolled in UEA Baraton table 4) had parents who were highly regarded people occupying professional/managerial $(36.0 \%)$ or semi-professional positions $(25.0 \%)$.

The chi-square test of independence result shows that the relationship between the type of secondary school attended and respondents' fathers occupations was significant with $\chi 2=$ $66.6 ; 8 \mathrm{df} ; \mathrm{p}<.001$. In other words, the two variables, type of secondary school attended and respondents fathers' occupation, are dependent in the population of first year students from which this sample was randomly drawn. Type of school attended is associated with the occupation of respondents' father.

\section{Summary of the Research Findings}

The table below provides a summary of respondents' socio-economic characteristics in the three institutions in which this study was done.

Table 7. A Summary of Respondents' Socio-economic Characteristics by Institutions

\begin{tabular}{|c|c|c|c|}
\hline Items & Moi University & UEA, Baraton & $\begin{array}{l}\text { Eldoret } \\
\text { Polytechnic }\end{array}$ \\
\hline Fathers' Education & $\begin{array}{l}\text { No formal } \\
\text { Primary }\end{array}$ & University & $\begin{array}{l}\text { Primary/ } \\
\text { Secondary }\end{array}$ \\
\hline Fathers' Occupation & $\begin{array}{l}\text { Farming / } \\
\text { Semi-skilled } \\
\text { manual }\end{array}$ & $\begin{array}{l}\text { Professional/ } \\
\text { Managerial }\end{array}$ & $\begin{array}{l}\text { Middle-level/ } \\
\text { Skilled }\end{array}$ \\
\hline $\begin{array}{l}\text { Mothers' Education } \\
\text { Schools Respondents } \\
\text { Attended }\end{array}$ & $\begin{array}{l}\text { No formal } \\
\text { District }\end{array}$ & $\begin{array}{l}\text { University/Secondary } \\
\text { National }\end{array}$ & $\begin{array}{l}\text { Primary } \\
\text { Provincial/ } \\
\text { District }\end{array}$ \\
\hline
\end{tabular}

\section{Discussions and Conclusion}

The results of this study indicate that, generally, students from all socio-economic backgrounds are enrolled in higher education. However, a small trickle of young people from poor homes appears to make their way into and through higher education. This is an indication that progression to higher education is unequal across socio-economic groups (see table 1, $2 \& 5$ ). The overall picture therefore suggests that benefits of higher education are disproportionately enjoyed by the middle and upper status families whose children in any case are more likely to attend highly rated secondary schools in this case provincial and national andare able to complete schooling with better grades.

It also appears that the economic capacity of parents is very crucial in determining who can 
take advantage of the best available education provision and how far a student goes up the education ladder as indicated by respondents at UEA Baraton a fee paying private institutions who were more likely to have fathers from high socioeconomic backgrounds SES(V)(27.4\%) than at Eldoret polytechnic (5.1\%) and Moi University (3.9\%). These results are consistent with those by Crawford 2014; Universities in Australia 2008; James, 2002; Knight and Sabot 1990; Ziderman and Albrecht, 1995that found higher education to be selective, not only across SES indicated by parental traits such as father's education and occupation but also in terms of the characteristics of secondary schools students attended. This study shows that there is a relationship between parental levels of education and young people's likelihood of pursuing higher education studies. The results of this study confirm those by Naidoo, (2007) who found that higher education participation rates were highest for children whose parents were from professional backgrounds as opposed to lower status occupational groups.

The findings with respect to respondents' parental level of education produced a highly significant chi-square value $(\chi 2=47.9 ; 6 \mathrm{df} ; \mathrm{p}<.001)$ indicating that highly educated parents with the ability to pay high fees enrolled their children at UEA Baraton followed by Eldoret polytechnic. Similarly respondents at UEA Baraton were most likely to have mothers with University education (34.2\%) compared to Eldoret Polytechnic (7.1\%) and Moi University $(6.7 \%)$; indicating a positive association between better educated mothers and the likelihood of students attending better rated secondary schools and thereby increasing their chances of access to higher education. These results also appear to confirm the findings by Sabot et al (1982) that there is a tendency for people to choose marriage partners with socio-economic characteristics similar to their own. This scenario of assortative mating makes access to higher education now and in the next generation more inequitable (James 2012; James 2002; Stevenson et al, 2000; Western 1998). Such inequalities tend to be carried over from one generation to another.

This study also confirms social selection and class bias in higher education and corroborates particularly recent study by Crawford (2014) on the link between secondary school characteristics and higher education participation and outcomes in UK. The findings established by this study make higher education access in Kenya highly inequitable.

Further, the findings of this study corroborate research by Maundu (1988) that found a correlation between school characteristics and socio-economic background of students. He established that a higher proportion of students enrolled in extra provincial (national schools) were children of educated men with at least form four level of education. Also found that the level of education of fathers of students in the other two types of schools, provincial and district, were relatively lower with the district having the lowest educationjust as was found in this study. In other words highly selective secondary schools in this case provincial and national are proxy for high SES and is highly correlated with high student achievement while less selective schools(district) is proxy to low SES and is correlated with low student achievement (see tables 2, $6 \& 5$ ).

The following is a summary of the research findings based on the research questions of who goes to higher education in Kenya. The findings indicate that: 
- Students from all socio-economic backgrounds are enrolled in higher education with those from low SES being under-represented.

- There are more students from lower status households in public universities and underrepresented polytechnicsand private universities.

- Students from middle and upper socio-economic backgrounds are more likely to study at the Polytechnic.

- Students in private universities are preponderantly of middle/upper socio-economic backgrounds.

- Students from middle and upper socio-economic backgrounds, that is, children of "professionals" are more likely to have attended the top rated secondary schools,provincial and national schools, which are correlated with high student achievement and therefore students have better chance of accessing higher education.

\section{Recommendations}

The findings of this study raise a number of considerations for education policy consisting of a number of inter-related policy and research initiatives. In order to achieve equity and enhance access to tertiary level education, amongst all socio-economic groups, the government should seriously address disparities in school outcomes, both at primary school level and between the various secondary school types and barriers to access that are due financial obstacles. This is absolutely necessary considering that equality of educational participation in higher education is directly dependent upon equality of access at the lower levels of the education system; differential access rates do not arise simply at the point of entry to university but that emerge relatively early in individuals' lives. Addressing issues of outcomes at lower levels will help to considerablyreduce socioeconomic status differences at higher education level.

The current practice of competitive entry and selection procedures based on school achievement may require rethinking to increase the participation of students from lower socioeconomic backgrounds in higher education. Furthermore, new entrants in higher education shouldbe allowed to choose courses and higher education institutions they wish to study at (private or public) without any restrictions through the introduction of the voucher system of financing higher education as a way of broadening access to higher education. In other words address factors caused by demand side as well

\section{Limitations and Areas of Further Research}

The study's findings point to at least three areas for further research. First, there were a few limitations in trying to interpret the results. The analysis is based on a much smaller number of respondents (581 compared to 10,000) drawn from only three institutions compared to ten 
institutions of higher education. The results included in this study might not therefore accurately reflect all the characteristics of students enrolled in higher education in Kenya when the results are generalized to the population of students in higher education. Likewise although some column counts were very small it did not in anyway neither invalidate the findings of this study nor violate the assumptions chi-square test statistic since not more than $20 \%$ of the cells had expected counts less than 5. In this regard there is need to undertake a similar study with a large sample and from more institutions of higher education.

Second there is need to undertake a comprehensive survey of socio-economic background of students and courses they are enrolled at higher education to determine the influence of type of school attended, parents education and occupation. Further,on their aspirations and expectations regarding education and the intentions of going on to higher education.

Three, a cohort study involving secondary school students, from different school types and backgrounds be undertaken up to the stage of higher education entrance in order to assess their educational progress and to determine how socio-economic background differences are reinforced or even increased at higher education. In other words vertical dimension of equity equally deserves as is horizontal of further analysis,

\section{References}

Baum, S., Ma, J., \& Payea, K. (2013). Education pays: The benefits of higher education for individuals and society. Washington, DC: The College Board. http://trends.collegeboard.org/sites/default/files/education-pays-2013-full-report.pdf?exc mpid=SM47-ED-ADV-tw

Blanden, J., \& Machin, S. (2004). Educational inequality and the expansion of UK higher education. Scottish Journal of Political Economy, Special Issue on the Economics of Education, 51, 230-49. http://dx.doi.org/10.1111/j.0036-9292.2004.00304.x

Blanden, J., \& Gregg, P. (2004). Family income and educational attainment: a review of approaches and evidence for Britain. Oxford Review of Economic Policy, 20, 245-63. http://dx.doi.org/10.1093/oxrep/grh014

Bowden, M.P., \& Doughney, J. (2010). Socio-economic status, cultural diversity and the aspirations of secondary students in the Western Suburbs of Melbourne, Australia. Higher Education, 59(1), 115-129. http://dx.doi.org/10.1007/s10734-009-9238-5

Bryman, A. (2007). Barriers to Integrating Quantitative and Qualitative Research. Journal of Mixed Methods Research, 1, 8-22. http://dx.doi.org/10.1177/2345678906290531

Burke, J., \& Chritensen, L. (2012). Educational Research: Quantitative, Qualitative and Mixed Approaches. Thousand Oaks, CA: SAGE Publications, Inc.

Chowdry, H., C. Crawford, L. Dearden, A. Goodman \& A. Vignoles (2013). Widening participation in higher education: analysis using linked administrative data. Journal of the Royal Statistical Society: Series A, 176, 431-457. 
http://dx.doi.org/10.1111/j.1467-985X.2012.01043.x

Crawford, C. (2014). The link between secondary school characteristics and HE participation and outcomes, CAYT Research Report https://www.gov.uk/government/publications/secondary-school-characteristics and-university-participation

Creswell, J. W. (2011). Mapping the developing landscape of mixed methods research. In A. Tashakkori \& C. Teddlie (Eds.), SAGE handbook of mixed methods in social and behavioral research (2nd ed., pp. 45-68). Thousand Oaks, CA: Sage.

Creswell, J. W. (2012). Educational research: planning, conducting, and evaluating quantitative and qualitative research $\left(4^{\text {th }}\right.$ ed.). Thousand Oaks, CA: Sage.

Hair, J.F., Black, W.C., Babin, B.J., \& Anderson, R.E. (2010). Multivariate Data Analysis (17th Ed.). Prentice Hall, Upper Saddle River, New Jersey.

James, R. (2002). Socioeconomic Background and Higher Education Participation: An analysis of school students' aspirations and expectations, Report submitted to the Evaluations and Investigations Programme, Department of Education, Science and Training, April.

James, R. (2012). Social Inclusion in a Globalised Higher Education Environment: The Issue of Equitable Access to University in Australia, pp. 83-108. In S. Tomlinson and T.N. Basit (eds.), Social Exclusion in Higher Education. Bristol: Policy Press.

Knight J. B., \& Sabot R. H. (1990). Education, Productivity and Inequality. The Eastern African Natural Experiment, Washington, DC, the World Bank.

Machin, S., \& Vignoles, A. (2004). Educational inequality: the widening socioeconomic gap. Fiscal Studies, 25, 107-28. http://dx.doi.org/10.1111/j.1475-5890.2004.tb00099.x

Maundu, J. N. (1988). Family background and Student Achievement. Kenya Journal of Education, 4(1), 53-87.

Naidoo, R. (2007). Higher education as a global commodity: the perils and promises for developing countries. London: The Observatory on Borderless Higher Education.

OECD (2006a). Education at a Glance. Paris: OECD.

OECD (2006b). Higher Education in Ireland. (Reviews of National Policies for Higher Education) Paris: OECD.

Psacharopoulus, G., \& Patrinos, H. A. (2004). Returns to Investment in Education: A Further Update. Education Economics, $12(2), \quad 111-134$. http://dx.doi.org/10.1080/0964529042000239140

Sabot, R. Berry, A., Hazlewood, A., \& Knight, J. (1982). Urban Employees in Kenya and Tanzania, Educational Attainment and its Relation to Jobs, Pay, Mobility and Rural Links, Mimeo, World Bank, Washington DC. 
Schuller, T., Preston, J., Hammond, C., Brassett-Grundy, A., \& Bynner, J. (2004). The Benefits of Learning: the impact of education on health, family life and social capital London: Routledge Falmer.

Stevenson, S., Evans, C., Maclachlan, M., Karmel, T., \& Blakers, R. (2000). Access: Effect of campus proximity and socioeconomic status on university participation in regions. Higher Education Division Occasional Paper Series, AGPS, Canberra.

Universities Australia (2008). Advancing Equity and Participation in Australian Higher Education: Action to address participation and equity levels in higher education of people from low socio-economic backgrounds and Indigenous people, Universities Australia, April.

Western, J., McMillan, J., \& Durrington, D. (1998). Differential Access to Higher Education: The measurement of socioeconomic status, rurality and isolation, Report submitted to the Evaluations and Investigations Programme, Department of Employment, Education, Training and Youth Affairs, June.

Winter, G. (2000). A comparative discussion ofthe notion of validity in qualitative and quantitative research. The Qualitative Report, 4(3\&4).

World Bank, (1995). Priorities and Strategies for Education. Washington DC, The Word Bank.

\section{Copyright Disclaimer}

Copyright for this article is retained by the author(s), with first publication rights granted to the journal.

This is an open-access article distributed under the terms and conditions of the Creative Commons Attribution license (http://creativecommons.org/licenses/by/3.0/). 